\title{
Lesser Grison (Galictis cuja Molina, 1782) as host of Dioctophyme renale Goeze, 1782
}

\author{
Furão Pequeno (Galictis cuja Molina, 1782) \\ como hospedeiro de Dioctophyme renale Goeze, 1782
}

Daniela Pedrassani ${ }^{1 *}$, Mayana Worm ${ }^{1}$, Jéssica Drechmer ${ }^{1}$, Margareth Cristina lazzetti Santos ${ }^{1}$

(1)

\begin{abstract}
The Dioctophyme renale is a helminth parasite of the kidney usually seen in domestic and wild carnivores and rarely in human beings. This is a report about the parasitism of $D$. renale found in the kidney of two roadkill lesser grisons (Galictis cuja) in the North of the state of Santa Catarina, Brazil. The report of this parasitism in this species is important to complement the records about this native carnivore as a contributor in the epidemiologic chain while host/disseminator of this helminth with zoonotic potential.
\end{abstract}

KEYWORDS: Dioctophyma; wild animal; mustelids; roadkill; kidney parasitism.
RESUMO: O Dioctophyme renale é um helminto parasita renal observado normalmente em carnívoros domésticos e silvestres e excepcionalmente em seres humanos. Relata-se o parasitismo por $D$. renale em rim de dois furôes pequenos (Galictis cuja) encontrados mortos por atropelamento no Norte do estado de Santa Catarina, Brasil. Relatar esse parasitismo nessa espécie é importante, para que se possam somar dados relativos a participação deste carnívoro nativo na cadeia epidemiológica como hospedeiro/ veiculador desse helminto com potencial zoonótico.

PALAVRAS-CHAVE: Dioctophyma; animal silvestre; mustelídeo; atropelamento em rodovia; parasitismo renal. 
The lesser grison (Galictis cuja) is a mammal that belongs to the Mustelidae Family, Order Carnivora and can be found in South America, from East to South in Brazil (REID; HELGEN, 2008). It frequently occurs near water but can also be seen in opened (MARES et al., 1989) and agricultural areas (REID; HELGEN, 2008). Its diet consists mainly of small and medium-sized vertebrates such as rodents, lagomorphs, birds, frogs, lizards, snakes and eggs (QUINTANA et al., 2000). This species is not in the Brazilian List of Endangered Fauna (MACHADO et al., 2005) and is considered least concern by the Red List of Threatened Species of the International Union for Conservation of Nature (IUCN) (IUCN, 2014). However it is important to note that its population is unknown.

According to VIEIRA (1996), G. cuja is the fifth most often road killed mammal species in Central Brazil, corresponding to $6.1 \%$ of all roadkill in the region. Considering that the consequences of parasitic diseases in this species increase the incidence of roadkill, researches about the helminth fauna of wild animals are as important to the wildlife conservation as to public health (LAFFERTY, 1997), since some of the parasites have a zoonotic potential.

The study of endoparasites of wild animals is important in order to comprehend the ecology, natural history, life cycle, and evolution of both parasites and hosts (SILVA et al., 2008). Brazil lacks researches in this filed. The aim of this study is to report Dioctophyme renale parasitism of two specimens of Galictis cuja in the north of Santa Catarina state, Brazil, in a region where there is a large incidence of this nematode in domestic dogs (PEDRASSANI; CAMARGO, 2004; PEDRASSANI et al., 2009).

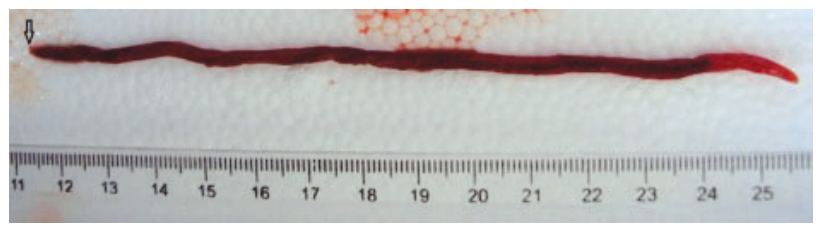

Figure 1. Dioctophyme renale removed from right kidney of Galictis cuja. Note: The black arrow indicates the male copulatory muscular bursa.

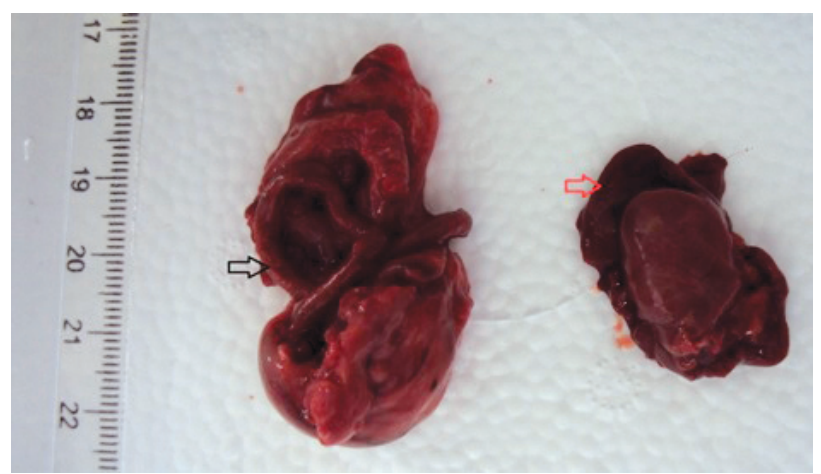

Figure 2. Kidneys from necropsied Galictis cuja. Right kidney increased in size and parasited by Dioctophyme renale (black arrow) and left kidney with normal size and absence of parasitism (red arrow).
Two G. cuja used in this study were found dead in a local highway in Canoinhas, Santa Catarina state (latitude 266'1,02"S; longitude 50'17 23'27,26”O), and both had signs of a recent roadkill. The carcasses were placed in isothermal boxes and sent to Universidade do Contestado for necropsy. The parasites found were washed in saline solution $0.9 \%$, fixed in alcohol $70^{\circ}$, analyzed in a stereoscopic microscope, identified, and morphologically classified according to the classification key (ANDERSON; BAIN, 1982).

The first specimen was an adult female G. cuja, found in October 2014. Its necropsy revealed a male Dioctophyme renale parasite in the right kidney, measuring a total $14.8 \mathrm{~cm}$ in length and $0.45 \mathrm{~cm}$ in diameter (Fig. 1). The right kidney was dysmorphic and hypertrophied and just a small amount of its parenchyma was preserved (Fig. 2). The left kidney was apparently intact (Fig. 2).

The second lesser grison was found in November 2014 and was also an adult female. Its necropsy revealed a $D$. renale female parasite in the right kidney, measuring $23.3 \mathrm{~cm}$ in length and $0.6 \mathrm{~cm}$ in diameter. The right kidney was dysmorphic and due to mechanic and enzymatic actions of the helminth — its parenchyma was nearly destroyed; just a portion of the cortical remained. Some parasites (Crenosoma sp.) were also found in its bronchioles (PEDRASSANI et al., 2015).

The Dioctophyme renale (Goeze, 1782) Collet-Meygret, 1802 (Dioctophymatidae), known as the giant kidney worm, is distributed worldwide and is frequently reported as a parasite of domestic (mainly dogs) and wild carnivores (MONTEIRO et al., 2002; PEDRASSANI et al., 2009; PESENTI et al., 2012; RIBEIRO et al., 2009; ZABOTT et al., 2012). In the Neotropical region, many carnivore species have already been reported as a definitive host, such as the maned wolf (Chrysocyon brachyurus), the crab-eating raccoon (Procyon cancrivorus), the vinegar $\operatorname{dog}$ (Speothos venaticus), the South American coati (Nasua nasua), the crab-eating fox (Cedocyon thous) and the lesser and greater grisson (Galictis cuja and G. vittata) (BARROS et al., 1990; REIS et al., 2006; PEDRASSANI et al., 2009; PESENTI et al., 2012; ZABOTT et al., 2012).

This parasite is found in the kidney (mostly in the right one) or loose inside the abdominal cavity of its hosts. When inside the kidney, it causes a progressive destruction of the cortical and medullar layers, and the kidney is reduced to a fibrous capsule (LEITE et al., 2005; PEDRASSANI et al., 2009).

The definitive host is infected by the direct ingestion of the intermediate host, an aquatic oligochaeta annelida (Lumbriculus variegatus), when the latter is infected by the parasite larvae in its third stage (infecting larvae). Another way of infection is through the ingestion of the paratenic host, fishes and frogs (MEASURES; ANDERSON, 1985; PEDRASSANI et al., 2009).

In São Cristóvão District, municipality of Três Barras, Santa Catarina state, which is separated from the municipality of Canoinhas by the Canoinhas River, the parasitism of $D$. renale is frequently observed in domestic dogs (PEDRASSANI; CAMARGO, 2004). According to local studies, there is a 
prevalence of $5.17 \%$ of $D$. renale larves in Chaunus ictericus (PEDRASSANI et al., 2009), an amphibian with a wide geographic distribution. C. ictericus has an easy adaptability to modified environments and it is commonly found near human habitations (SABAGH; CARVALHO-E-SILVA, 2008).

The Highway where both lesser grisons were found is close to Canoinhas River and São Cristóvão District (SC). According to QUINTANA et al. (2000), the lesser grison's diet includes toads as the C. Ictericus found in this region. These facts corroborate with previous studies (PEDRASSANI;
CAMARGO, 2004; PEDRASSANI et al., 2009), indicating that the $D$. renale is endemic to this location.

There aren't many studies about wild animals roadkills in Santa Catarina, but COSTA (2011) reported that the G. cuja is the third most common one - among small and medium sized mammals - on BR 101 Highway (north of the state). Since two infected specimens were found in a short period, it is believed that the cycle of the $D$. renale on lesser grisson developed sustainable ways of surviving. Considering its zoonotic nature, the parasitism in this area should be continuously monitored.

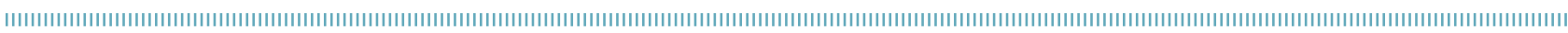
REFERENCES

ANDERSON, R.C.; BAIN, O. Keys to genera of the superfamilies Rhabditoidea, Dioctophymatoidea, Trichinelloidea and Muspiceoidea, n. 9. In: ANDERSON, R.C.; CHABAUD, A.G.; WILLMOTT, S. CIH Keys to the Nematode Parasites of Vertebrates. Wallingford: CAB International, 1982. p.15-16.

BARROS, D.M.; LORINI, M.L.; PERSSON, V.G. Dioctophymosis in the Little Grison (Galictis cuja). Journal of Wildlife Diseases, v.26, n.4, p.538-539, 1990.

COSTA, L.S. Levantamento de mamíferos silvestres de pequeno e médio porte atropelados na BR 101, entre os municípios de Joinville e Piçarras, Santa Catarina. Bioscience Journal, Uberlândia, v.27, n.4, p.666-672, 2011.

INTERNATIONAL UNION FOR CONSERVATION OF NATURE AND NATURAL RESOURCES (IUCN). The IUCN Red List of Threatened Species. Version 2014.3. Available from: <http://www.iucnredlist. org>. Accessed on: 2014 Dec 4.

LAFFERTY, K.D. Envirommental parasitology, what can parasites tell us about human impact on the environment? Parasitology Today, Cambridge, v.13, p.251-255, 1997.

LEITE, L.C.; CÍRIO, S.M.; DINIZ, J.M.F.; LUZ, E.; NAVARRO-SILVA, M.A.; SILVA, A.W.C.; LEITE, S.C.; ZADOROSNEI, A.C.; MUSIAT, K.C.; VERONESI, E.M.; PEREIRA, C.C. Anatomopathologic lesions found in Dioctophyma renale (Goeze, 1782) infections in domestic dogs (Canis familiaris, Linnaeus, 1758). Archives of Veterinary Science, Curitiba, v.10, n.1, p.95-101, 2005.

MACHADO, A.B.M.; MARTINS, C.S.; DRUMMOND, G.M. Lista da fauna brasileira ameaçada de extinção: incluindo as espécies quase ameaçadas e deficientes em dados. Belo Horizonte: Fundação Biodiversitas, 2005. 158p.

MARES, M.; OJEDA, R.; BARQUEZ, R. Guide to the mammals of Salta Province, Argentina. Norman: University of Oklahoma Press, Norman, 1989.

MEASURES, L.N.; ANDERSON, R.C. Centrarchid fish as paratenic hosts of the giant kidney worm, Dioctophyma renale (Goeze,
1782), in Ontario, Canada. Journal of Wildlife Diseases, v.21, p.11-19, 1985.

MONTEIRO, S.G., SALLIS, E.S.V.; STAINKI, D.R. Infecção natural por trinta e quatro helmintos da espécie Dioctophyma renale (Goeze, 1782) em um cão. Revista da Faculdade de Zootecnia, Veterinária e Agronomia de Uruguaiana, v.9, p. 29-32, 2002.

PEDRASSANI, D.; CAMARGO, F.R. Dioctofimose em cães: primeiro relato da ocorrência de casos no Distrito São Cristóvão, Três Barras - SC. Revista Brasileira de Parasitologia Veterinária, v.13, suppl.1, p.283, 2004.

PEDRASSANI, D.; HOPPE, E.G.L.; TEBALDI, J.H.; NASCIMENTO, A.A. Chaunus ictericus (Spix, 1824) as paratenic host of the giant kidney worm Dioctophyme renale (Goeze, 1782) (Nematoda: Enoplida) in São Cristóvão district, Três Barras county, Santa Catarina state, Brazil. Veterinary Parasitology, v. 165, n.1-2, p.74-77, 2009.

PEDRASSANI, D.; SANTOS, M.C.I.; MIREK, T.C.; WENDT, L.A.; DRECHMER, J.; WORM, M.R. Primeiro relato de caso de Crenosoma sp. em furão pequeno (Galictis cuja, Molina, 1782) no estado de Santa Catarina, Sul do Brasil. In: CONGRESSO BRASILEIRO DE MEDICINA VETERINÁRIA, 42., CONGRESSO SUL-BRASILEIRO DA ASSOCIAÇÃO NACIONAL DE CLÍNICOS VETERINÁRIOS DE PEQUENOS ANIMAIS, 1., Curitiba, 2015. Anais... 2015. Available from: <http://www. infoteca.inf.br/conbravet/smarty/templates/arquivos_template/ upload_arquivos/acervo/347.pdf>. Accessed on: 2016 Apr. 4.

PESENTI, T.C.; MASCARENHAS, C.S.; KRÜGER, C.; SINKOC, A.L.; ALBANO, A.P.N.; COIMBRA, M.A.A.; MÜLLER, G. Dioctophyma renale (Goeze, 1782) Collet- Meygret, 1802 (Dioctophymatidae) in Galictis cuja (Molina, 1782) (Mustelidae) in Rio Grande do Sul, Brazil. Neotropical Helminthology, v.6, n.2, p.301-305, 2012.

QUINTANA, V.; YÁÑEZ, J.; VALDEBENITO, M. Order Carnivora. In: PEDREROS, A.M.; YÁÑEZ VALENZUELA, J. Mamíferos de Chile. Valdivia: Ediciones CEA, 2000. p.155-187.

REID, F.; HELGEN, K. Galictis cuja. The IUCN Red List of Threatened Species. Version 2014.3. 2008. Available from: <www.iucnredlist. org>. Accessed on: 2014 Nov 19. 
REIS, L.S.; MARTUCCI, M.F.; BELLATINE, T.; CARVALHO, A.F.; VARZIM, F.L.S.D. Relato de Ocorrência de Dioctophyma renale em Mão pelada (Procyon cancrivorous) do Criatório em São João da Boa Vista, SP. In: CONGRESSO BRASILEIRO DE PARASITOLOGIA VETERINÁRIA, 14., Ribeirão Preto. Anais... p.276, 2006.

RIBEIRO, C.R.; VEROCAI, G.G.; TAVARES, L.E.R. Dioctophyma renale (Nematoda, Dioctopymatidae) infection in the crabeating Fox (Cerdocyon thous) from Brazil. Journal Wildlife Diseases, v.45, p.248-250, 2009.

SABAGH, L.T.; CARVALHO-E-SILVA, A.M.P.T. Feeding overlap in two sympatric species of Rhinella (Anura: Bufonidae) of the Atlantic Rain Forest. Revista Brasileira de Zoologia, Curitiba, v.25, n.2, p.247-253, 2008.
SILVA, A.S.; ZANETTE, R.A.; TOCHETTO, C.; OLIVEIRA, C.B.; SOARES, J.F.; OTTO, M.A.; MONTEIRO, S.G. Parasitismo por Physaloptera sp., Kalicephalus sp. e Cryptosporidium sp. em lagarto (Tupinambis teguixin) no Rio Grande do Sul, Brasil. Revista Brasileira de Zoociências, v. 10, n.3, p.271-274, 2008.

VIEIRA, E.M. Highway mortality of mammals in central Brazil. Ciencia y Cultura. Journal of the Brazilian Association for the Advancement of Science, p.270-272, 1996.

ZABOTT, M.V.; PINTO, S.B.; VIOTT, A.M.; TOSTES, R.A.; BITTENCOURT, L.H.F.B.; KONELL, A.L.; GRUCHOUSKEI, L. Occurrence of Dioctophyma renale in Galictis cuja. Pesquisa Veterinária Brasileira, v.32, n.8, p.786-788, 2012. 